\title{
Halogeometricum borinquense gen. nov., sp. nov., a novel halophilic archaeon from Puerto Rico
}

\author{
Rafael Montalvo-Rodríguez, ${ }^{1}$ Russell H. Vreeland, ${ }^{2}$ Aharon Oren, ${ }^{3}$ \\ Martin Kessel, ${ }^{4}$ Carlos Betancourt ${ }^{1}$ and Juan López-Garriga ${ }^{5}$
}

Author for correspondence: Juan López-Garriga. Tel/Fax: +1 7872655453. e-mail: sonw a caribe.net

\footnotetext{
1 Biology Department, University of Puerto Rico, Mayaguez Campus,

Mayaguez, PR 00680-5000, Puerto Rico

2 Department of Biology, West Chester University, West Chester, PA 19383, USA

3 Division of Microbial and Molecular Ecology, and the Moshe Shilo Minerva Center for Marine Biogeochemistry, The Hebrew University of Jerusalem, Jerusalem 91904, Israel

${ }^{4}$ Department of Membrane and Ultrastructure Research, The Hebrew University - Hadassah Medical School, POB 12272, Jerusalem, 91110 , Israel

5 Department of Chemistry, University of Puerto Rico, Mayaguez Campus, Mayaguez, PR 00680-5000, Puerto Rico
}

\begin{abstract}
A novel extremely halophilic archaeon was isolated from the solar salterns of Cabo Rojo, Puerto Rico. The organism is very pleomorphic, motile and requires

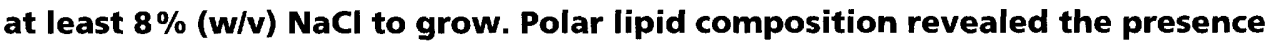
of a novel non-sulfate-containing glycolipid and the absence of the glycerol diether analogue of phosphatidylglycerosulfate. The G+C content of the DNA is $59 \mathrm{~mol} \%$. On the basis of 165 rRNA sequence data, the new isolate cannot be classified in one of the recognized genera, but occupies a position that is distantly related to the genus Haloferax. All these features justify the creation of a new genus and a new species for the family Halobacteriaceae, order Halobacteriales. The name Halogeometricum borinquense gen. nov., sp. nov. is proposed. The type strain is ATCC 700274'.
\end{abstract}

Keywords: halophilic bacteria, Halogeometricum borinquense gen. nov., sp. nov., archaea

\section{INTRODUCTION}

The family Halobacteriaceae (order Halobacteriales, domain Archaea) presently contains ten recognized genera: Halobacterium, Haloarcula, Haloferax, Halococcus, Natronobacterium, Natronococcus, (Grant \& Larsen, 1990; Tindall et al., 1984; Tindall, 1992; Torreblanca et al., 1986), Halorubrum (McGenity \& Grant, 1995), Halobaculum (Oren et al., 1995), Natrialba (Kamekura \& Dyall-Smith, 1995) and Natronomonas (Kamekura et al., 1997). A primary characteristic of all Halobacteriaceae is a requirement for high salt concentrations, with a minimum of $1.5 \mathrm{M}$

The GenBank accession number for the $16 \mathrm{~S}$ rRNA sequence of $\mathrm{PR}^{\top}$ is AF002984. sodium chloride needed for growth (Norton, 1992). Most halobacteria grow optimally at $210-270 \mathrm{~g} \mathrm{NaCl}$ $1^{-1}$ (Grant \& Larsen, 1990; Norton, 1992).

In 1994, we isolated 20 halophilic archaeal strains from the solar salterns of Cabo Rojo, Puerto Rico. Three strains (designated PR3, PR7 and PR19) were similar in morphological and physiological properties and in lipid composition. They showed unique features that did not correspond to any previously described species (Grant \& Larsen, 1990; Kamekura \& Dyall-Smith, 1995; Tindall, 1992; Kamekura et al., 1997). Strain PR $3^{\mathrm{T}}$ ( $\mathrm{T}=$ type strain) was chosen for further characterization. Based on 16S rRNA sequences, polar lipid content and physiological analysis the creation of a new genus for the family Halobacteriaceae, order Halobacteriales appears to be justified. In this paper we present the characteristics of strain PR $3^{\mathrm{T}}$. 


\section{METHODS}

Collection of samples and isolation of halophilic archaea. Five water samples $(400 \mathrm{ml}$ each) were collected in sterile plastic bags (Whirl-Pak) from the solar salterns in Cabo Rojo, Puerto Rico, between May and August of 1994. Each sample was divided into $50 \mathrm{ml}$ aliquots, which were then filtered through $0.45 \mu \mathrm{m}$ and $0.22 \mu \mathrm{m}$ nitrocellulose membranes (Millipore). The membranes were transferred onto agar plates containing Seghal-Gibbons medium (Seghal \& Gibbons, 1960) (SG) or glycerol solar salt medium (GSS) $\left(250 \mathrm{~g}\right.$ solar salt $\mathrm{l}^{-1}, 10 \mathrm{~g}$ glycerol $\mathrm{l}^{-1}$ and $1 \mathrm{~g}$ Casamino acids $1^{-1}$ ). Inoculated plates were incubated in sealed bags at $40^{\circ} \mathrm{C}$. After $7 \mathrm{~d}$ incubation, representative colonies were transferred to SG broth medium. Pure cultures were obtained by the quadrant streak plate method.

The strains Halobacterium salinarum ATCC 19700, Haloferax mediterranei ATCC $33500^{\mathrm{T}}$, Halorubrum saccharovorum ATCC $29252^{\mathrm{T}}$, Haloarcula hispanica ATCC $33960^{\mathrm{T}}$, Haloarcula marismortui ATCC43049 ${ }^{\mathrm{T}}$, Haloarcula vallismortis ATCC 29715 ${ }^{\mathrm{T}}$, Halomonas elongata ATCC $33173^{\mathrm{T}}$, Escherichia coli ATCC 8677 and Pseudomonas aeruginosa ATCC 142 were used as reference strains in biochemical tests and in total and polar lipid analysis.

Morphological, cultural and physiological characteristics. Isolated strains were examined for motility and morphological features in wet mounts (Vreeland, 1993). Optimal conditions for growth were determined by growing each isolate in SG broth supplemented with $5,8,10,15,25$ and $30 \%(\mathrm{w} / \mathrm{v}) \mathrm{NaCl}$ and temperatures of $4,22,28,37,40$ and $50{ }^{\circ} \mathrm{C}$. The $\mathrm{pH}$ tolerance of each isolate was also tested in $\mathrm{SG}$ medium with $\mathrm{pH}$ values $4,6,7,8$ and 10 . The cultures were inoculated with $100 \mu \mathrm{l}$ of a late-exponential-phase culture grown at $37^{\circ} \mathrm{C}$ without shaking. All of the optimal conditions tests were incubated for $7 \mathrm{~d}$. The extent of growth was determined visually (Gonzalez et al., 1978; V reeland, 1993). Gram stains were prepared as described by Dussault (1955). Spore and capsule stains were performed according to the methods described by Murray et al. (1994). Minimal magnesium requirement for growth was determined using the optimal growth conditions determined above with variable amounts of $\mathrm{MgSO}_{4}$ (Ihara et al., 1997; Takashina et al., 1990).

Antibiotic sensitivity was tested by spreading bacterial suspensions on plates of SG medium and applying antibiotic discs (penicillin $10 \mathrm{IU}$, bacitracin $10 \mu \mathrm{g}$, novobiocin $30 \mu \mathrm{g}$, kanamycin $30 \mu \mathrm{g}$, ampicillin $30 \mu \mathrm{g}$, vancomycin $30 \mu \mathrm{g}$, sulfamethazone and trimethoprim $25 \mu \mathrm{g}$, tetracycline $30 \mu \mathrm{g}$, erythromycin $15 \mu \mathrm{g}$ and chloramphenicol $30 \mu \mathrm{g}$ ) (Bonelo et al., 1984; Colwell et al., 1979; Torreblanca et al., 1986). The results were recorded as sensitive or resistant after $14 \mathrm{~d}$ incubation at $40^{\circ} \mathrm{C}$, with sensitive being defined as the appearance of a zone of inhibition extending at least $2 \mathrm{~mm}$ beyond the antibiotic disc.

Lipid chromatography. Total lipid analysis was performed as described by Ross et al. (1981), without freeze-drying the cells. Three hundred milligrams of wet cells were used for lipid extraction. Polar lipid extraction and TLC was performed as described by Torreblanca et al. (1986) using single or double development. Plates were stained for glycolipids and other lipids using the $\alpha$-naphthol stain (Torreblanca et $a l ., 1986$ ) or the $\mathrm{CeSO}_{4}$ stain (Kates, 1972). The presence of sulfate groups on the separated lipids was determined using Azure A stain as described by Matsubara et al. (1994).

Biochemical tests. Nitrate reduction was tested in liquid SG medium supplemented with $0.1 \%(\mathrm{w} / \mathrm{v}) \mathrm{KNO}_{3}$ (Tindall $e t$ al., 1984). Formation of gaseous products from nitrate was detected by the presence of bubbles in Durham tubes (Vreeland, 1993). Anaerobic growth in the presence of either nitrate or arginine was tested as described previously (Hartmann et al., 1980; Hochstein \& Tomlinson, 1985; Mancinelli \& Hochstein, 1986). Production of acids from sugars was examined in phenol red broth base (BBL) supplemented with $25 \%$ (w/v) $\mathrm{NaCl}, 0 \cdot 2 \%$ (w/v) $\mathrm{KCl}$ and $2 \%(\mathrm{w} / \mathrm{v}) \quad \mathrm{MgSO}_{4} \cdot 7 \mathrm{H}_{2} \mathrm{O}$ (Thongthai et al., 1992). To determine the ability to use sugars as energy sources, the minimal medium of Rodríguez-Valera et al., (1980) was supplemented with $1 \%$ of the test sugar and $0.01 \%$ yeast extract. Control plates with $1 \%(\mathrm{w} / \mathrm{v})$ or $0.01 \%$ yeast extract were also inoculated. The result was considered positive when growth appeared on the control medium with $1 \%$ yeast extract and on the medium with the sugar being tested, but not on the $0 \cdot 01 \%$ yeast extract control (Rodriguez-Valera et al., 1983).

Indole production was detected by adding the Kovacs' reagent to the $\mathrm{SG}$ broth supplemented with $1 \%(\mathrm{w} / \mathrm{v})$ tryptone (Holding \& Collee, 1971; Takashina et al., 1990). To determine starch hydrolysis, the strains were streaked onto SG with $1 \%(\mathrm{w} / \mathrm{v})$ soluble starch and $2 \%(\mathrm{w} / \mathrm{v})$ Bactoagar, and the plates were flooded with iodine solution after growth was obtained (Takashina et al., 1990). Catalase was determined by adding a $1 \%(\mathrm{w} / \mathrm{v}) \mathrm{H}_{2} \mathrm{O}_{2}$ solution to colonies on SG agar medium. Gelatin hydrolysis was detected in SG supplemented with $1 \%(\mathrm{w} / \mathrm{v})$ gelatin. After 14 days, the tubes were examined for the presence of liquefaction (Holding \& Collee, 1971; Tomlinson \& Hochstein, 1976). The presence of oxidase was determined using the DRY SLIDE (Difco) biochemical test.

Phase-contrast microscopy. One millilitre of stationary phase cells was centrifuged into a pellet and resuspended in $0.5 \mathrm{ml}$ filter-sterilized brine containing $20 \%(\mathrm{w} / \mathrm{v}) \mathrm{NaCl}$. The cells were then mixed with an equal volume of melted $2 \%(\mathrm{w} / \mathrm{v})$ agarose containing $20 \%(\mathrm{w} / \mathrm{v}) \mathrm{NaCl}$. A single drop of this cell suspension was placed onto a clean microscope slide and allowed to harden. A cover slip was placed onto the drop of agar and the slide was placed into a $45^{\circ} \mathrm{C}$ oven and allowed to melt to form a thin $(10 \mu \mathrm{m})$ layer. The slide was then cooled and viewed using an Olympus BH phase-contrast microscope. Photographs of individual cells were obtained using an MTK-1 television camera fitted with a $20 \times$ ocular lens. Images were digitized and electronically enhanced using the Paint Shop Pro and Power Point editing programs. To enhance the view of the gas vesicles, selected images were digitally treated to a special effect of hot waxing using the Paint Shop Pro editing program. These digital images were printed using an Hewlett Packard 870Cse Deskjet printer system or a Techtronix Phaser II sublimation printer.

Electron microscopy. A $4 \mu \mathrm{l}$ drop of the culture was applied to a carbon-coated collodion-stabilized copper grid for $30 \mathrm{~s}$. The drop was washed away with 4-5 drops of $1 \%(\mathrm{w} / \mathrm{v})$ aqueous uranyl acetate and the grid allowed to air dry. Specimens were examined in a Philips CM12 transmission electron microscope operating at $100 \mathrm{kV}$. Micrographs were recorded at a nominal magnification of $\times 60000$ on Kodak emulsion SO-163 (Oren, 1983).

DNA base composition and 16S rRNA analysis. The $\mathrm{G}+\mathrm{C}$ content of the DNA and the 16S rRNA phylogenetic analyses were performed by the Deutsche Sammlung von Mikroorganismen und Zellkulturen, Braunschweig, Germany (DSMZ). The DNA for the $\mathrm{G}+\mathrm{C}$ content was 


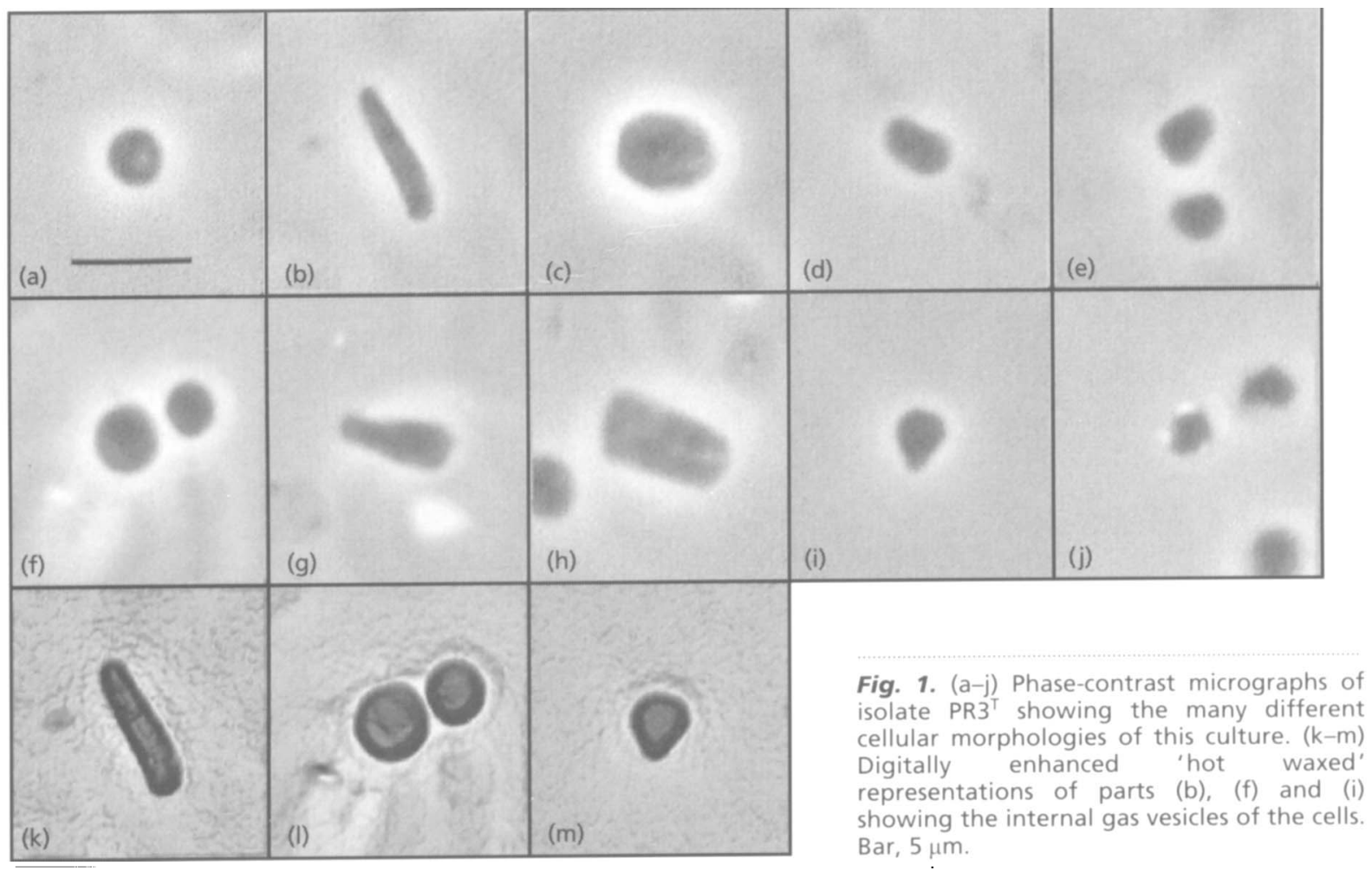

isolated and purified by chromatography on hydroxyapatite. The $\mathrm{G}+\mathrm{C}$ content was determined by HPLC.

Genomic DNA extraction, PCR mediated amplification of the $16 \mathrm{~S} \mathrm{rDNA}$ and purification of the PCR products was carried out as described previously (Barns et al., 1994; Rainey $e t$ ll., 1996). Purified PCR products were sequenced using the ABI PRISM Dye Terminator Cycle Sequencing Ready Reiction Kit (Applied Biosystems) as directed in the manufacturer's protocol. Sequence reactions were electrophoresed using the Applied Biosystems 373A DNA Sequencer. A total of 1451 bases corresponding to positions 19-1469 of the Haloferax mediterranei sequence (accession no. D11107) were identified during these analyses. Distance analysis of the resulting sequence of PR ${ }^{\mathrm{T}}$ was performed using the PHYLIP program (version 3.5.1) (Felsenstein, 1993). A multiple-sequence alignment was made by using the CLUSTAI. W program with $16 \mathrm{~S}$ rRNA gene sequences of organisms belonging to the extremely halophilic archaea (McGenity \& Grant, 1995; Kamekura \& Dyall-Smith, 1995; Oren et al. 1995; Maidak et al., 1996). The halophiles used and their corresponding accession numbers in parentheses were Halobacterium salinarum Y12 (D14127), Haloferax mediterranei (D11107), Halorubrum saccharovorum (X82167), Haloarcula vallismortis (D50851), Haloferax denitrificans (D14128), Haloferax gibbonsii (D13378), Haloferax volcunii (K00421), Halobaculum gomorrense (L37444), Halorubrum sodomense (D13379) and Natrialba asiatica B1T (D14124). Methanospirillum hungatei (M60880) served as the out group. The $16 \mathrm{~S}$ rRNA gene similarity values were calculated by pairwise comparison of the sequences within the alignment. SEQBOOT was used to generate 100 bootstrapped data sets. Distance matrices were calculated with DNADIST. One hundred trees were inferred by using NEIGHBOR. Any bias introduced by the order of sequence addition was minimized by randomizing the input order. CONSENSE was used to determine the most frequent branching order. The final tree was drawn using TREEVIEW (Page, 1996).

\section{RESULTS}

\section{Cell and colony morphology}

Three strains (designated PR3, PR7 and PR19) all isolated from isolated from Cabo Rojo proved to have very similar morphology, physiology and lipid compositions. Strain PR3 was studied in further detail and was designated the type strain of the new genus and species described below. Cells of isolate PR $3^{\mathrm{T}}$ were extremely pleomorphic showing different shapes (short and long rods, squares, triangles, ovals) when grown on SG broth (Fig. 1). Mean cell dimensions of the rod forms were $1-3 \times 1-2 \mu \mathrm{m}$. Motility in SG broth was due to peritrichous flagella (Fig. 2). Cells stained Gram-negative. Spores or capsules were not observed.

Colonies of $\mathrm{PR} 3^{\mathrm{T}}$ on SG medium were $0.5-1 \mathrm{~mm}$ in size, pink, very mucoid, circular in size, convex, with an entire margin after 1 week incubation at $40^{\circ} \mathrm{C}$, and had a milky appearance due to the presence of gas vesicles (Fig. 1k-m, and Fig. 2). On plates of GSS medium, growth was slower, and colonies were less pigmented.

\section{Cultural and biochemical characteristics}

Strain $\mathrm{PR} 3^{\mathrm{T}}$ required at least $8 \%(\mathrm{w} / \mathrm{v}) \mathrm{NaCl}$ to grow in $\mathrm{SG}$ medium. Optimum growth occurred at $20-25 \%$ $(\mathrm{w} / \mathrm{v}) \mathrm{NaCl}$ at $40^{\circ} \mathrm{C}$ and a $\mathrm{pH}$ of 7 . No growth was 


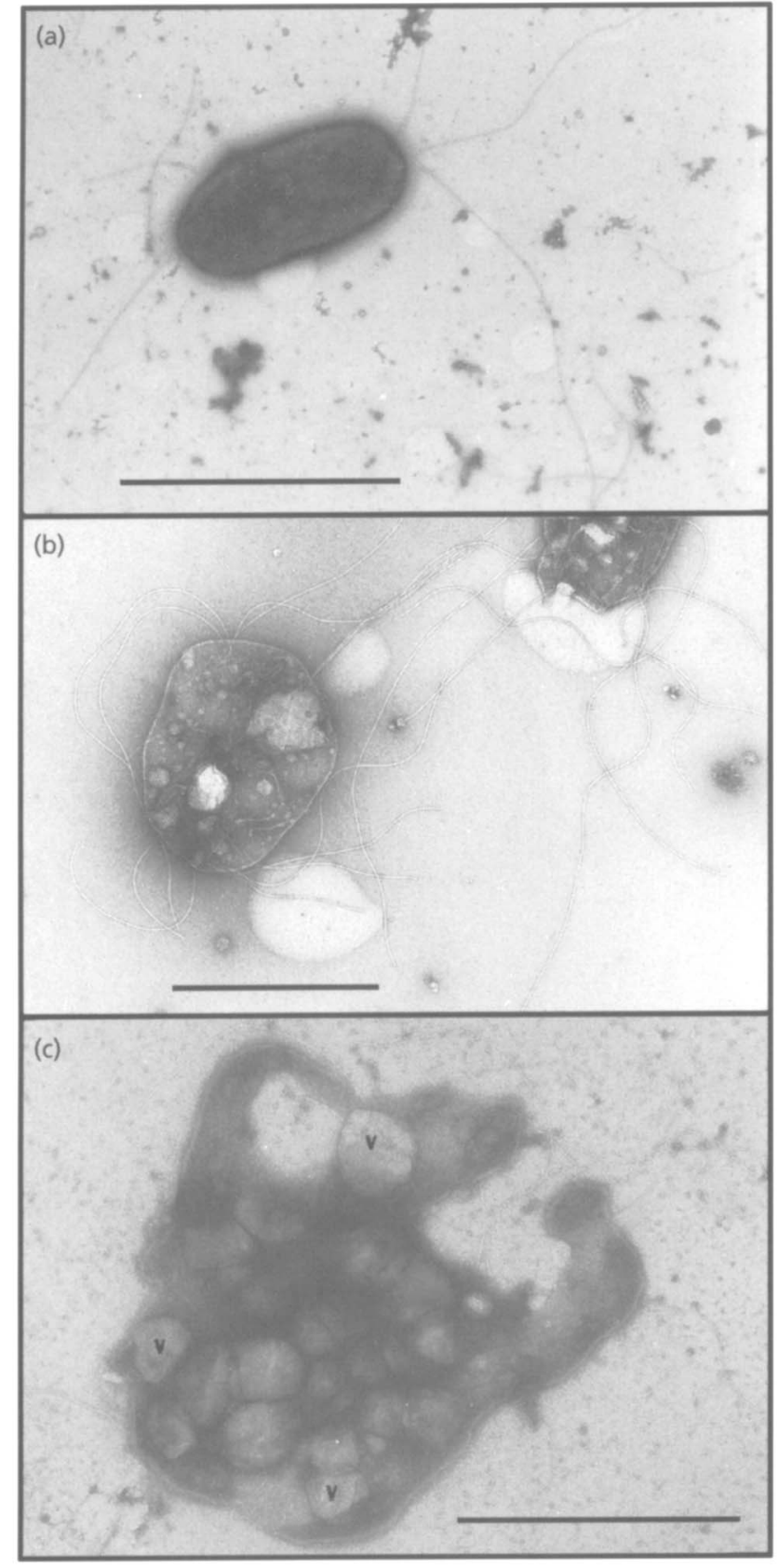

Fig. 2. Electron micrographs of negatively stained strain $P R 3^{\top}$ showing ( $a$ and $b$ ) peritrichous flagella and (c) gas vesicles (V). Bars, $1 \mu \mathrm{m}$.

observed below $22{ }^{\circ} \mathrm{C}$ or above $50^{\circ} \mathrm{C}$ and at $\mathrm{pH}$ values below 6 and above 8 . At optimal conditions of salinity, temperature and $\mathrm{pH}$, strain $\mathrm{PR} 3^{\mathrm{T}}$ could grow at very low magnesium concentrations. The best growth was obtained with $40-80 \mathrm{mM} \mathrm{Mg}^{2+}$.

The isolate showed positive catalase and oxidase reactions. Nitrite was produced from nitrate with gas production. PR $3^{\mathrm{T}}$ could grow anaerobically in the presence of nitrate. Strain PR $3^{\mathrm{T}}$ strongly hydrolysed gelatin. Starch was not hydrolysed. Indole was formed from tryptophan. Glucose, mannose, fructose, xylose, maltose, trehalose, cellobiose, raffinose and glycerol were used as carbon sources. Acid was produced from fructose, arabinose, ribose, xylose, lactose and sucrose. The organism was unable to grow anaerobically on arginine.

The strain was resistant to penicillin, kanamycin, ampicillin, vancomycin, tetracycline, erythromycin and chloramphenicol. Isolate PR3 ${ }^{\mathrm{T}}$ showed susceptibility to novobiocin, bacitracin and sulfamethazone plus trimethoprim.

\section{Lipid analyses}

Total lipid analysis of $P R 3^{\text {T }}$ revealed spots attributable to glycerol diether moieties, characteristic of the Archaea (Ross et al., 1981).

TLC of polar lipids showed that isolate PR $3^{\mathrm{T}}$ contains the glycerol diether analogues of phosphatidylglycerol (PG), phosphatidylglycerophosphate (PGP) and a single glycolipid (Fig. 3). This glycolipid runs somewhat faster on the TLC plate than TGD-2, the glycolipid marker of Haloarcula. Phosphatidylglycerosulfate (PGS), which is present in halophilic archaeal species of Haloarcula, Halobacterium, Halorubrum and Halococcus, was not detected in isolate PR $3^{\mathrm{T}}$.

\section{DNA base composition}

The $\mathrm{G}+\mathrm{C}$ content of the DNA of strain $P R 3^{\mathrm{T}}$ was $59 \mathrm{~mol} \%$. The $\mathrm{G}+\mathrm{C}$ content of the two similar strains designated PR7 and PR19, was 59.6 and $60.5 \mathrm{~mol} \%$ respectively.

\section{Phylogeny}

The data obtained from the 16S rRNA 1451 bases and the phylogenetic analysis reveal that strain PR3 ${ }^{\mathrm{T}}$ occupies a position that is distantly related to the members of the genus Haloferax (Fig. 4). The highest similarity value $(93.7 \%)$ exists with Haloferax volcanii ATCC $29605^{\mathrm{T}}$ (Table 1).

\section{DISCUSSION}

The presence of glycerol diether moieties indicates that isolate PR $3^{\mathrm{T}}$ is an extremely halophilic archaeon (Ross et al., 1981; Torreblanca et al., 1986). High salt requirement, resistance to kanamycin, chloramphenicol and penicillin (which inhibit growth of halophilic eubacteria) and susceptibility to bacitracin and novobiocin also place this strain into the Halobacteriales (Tindall, 1992; Torreblanca et al., 1986).

The polar lipid chromatogram of strain PR $3^{\mathrm{T}}$ showed a novel pattern (Fig. 3). The sole glycolipid of PR3 ${ }^{\mathrm{T}}$ behaved similar to the glycolipid of Haloarcula species $\left(1-O\right.$ - $\left[\beta\right.$-D-glucose- $\left(1^{\prime} \rightarrow 6^{\prime}\right)$ - $\alpha$-D-mannose- $\left(1^{\prime} \rightarrow 2^{\prime}\right)-\alpha$ D-glucose]-2,3-di- $O$-phytanyl-sn-glycerol [TGD-2]) 


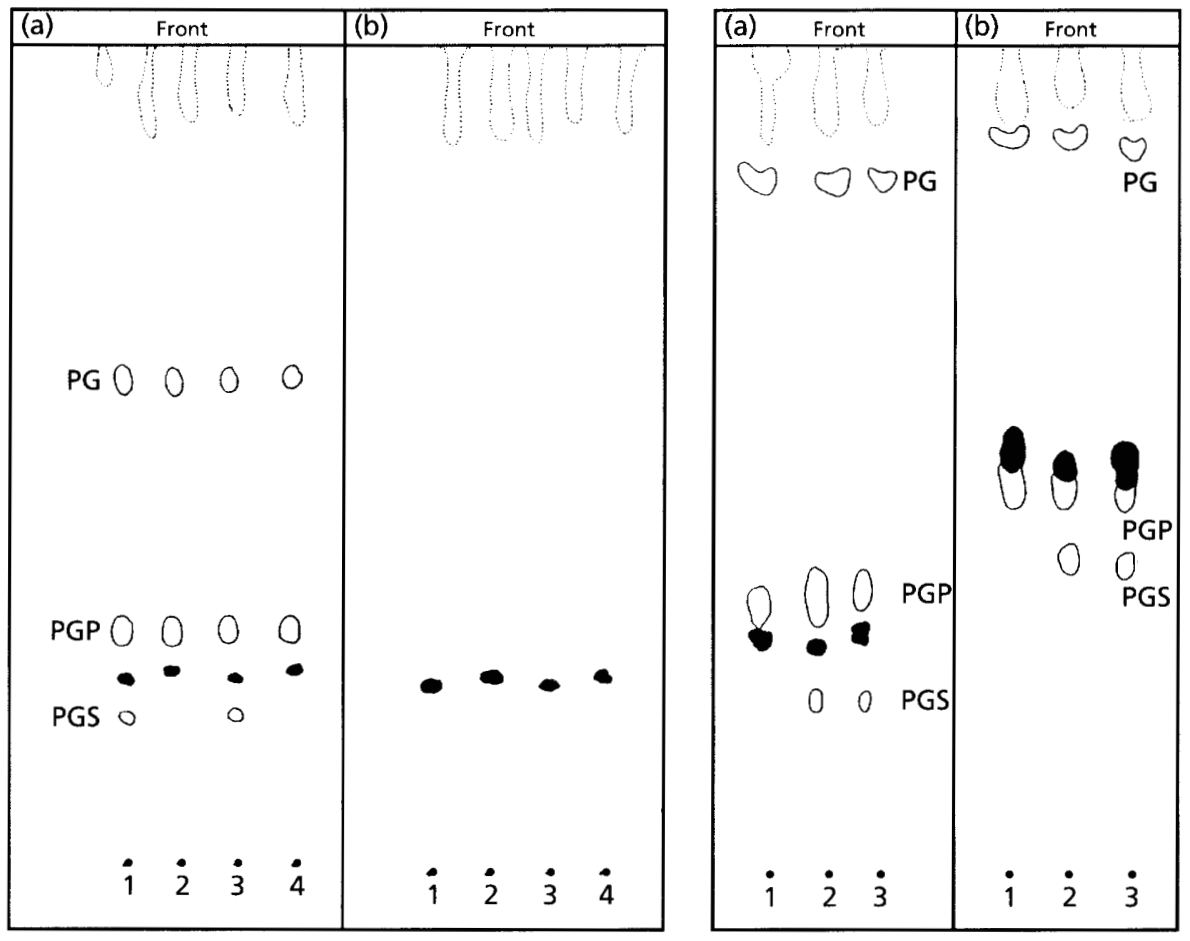

Fig. 3. Left-hand parts: thin-layer chromatogram of polar lipids extracted from strain PR3 (lanes 2 and 4), Haloarcula marismortui (lane 1) and Haloarcula vallismortis (lane 3). The silica gel plate was developed once with chloroform/methanol/acetic acid/water (80:12:15:4, by vol.) and was stained with $\mathrm{CeSO}_{4}$ (a) or with $\alpha$-naphthol (b). Dark spots indicate the position of glycolipids and clear spots indicate phospholipids. Right-hand parts: single development chromatography of polar lipids extracted from strain PR3 (lane 1), Haloarcula vallismortis (lane 2), and a mixture of strain PR3 and Haloarcula vallismortis (lane 3). The solvents used were chloroform/methanol/acetic acid/water [80:12:15:4, by vol. for (a); 85:22.5:10:4 for (b)], and plates were stained with $\mathrm{CeSO}_{4}$ to reveal all lipids. In all parts, dark spots indicate the position of glycolipids and clear spots indicate phospholipids. PGP, phosphatidylglycerophosphate; PG, phosphatidylglycerol; and PGS, phosphatidylglycerosulfate.

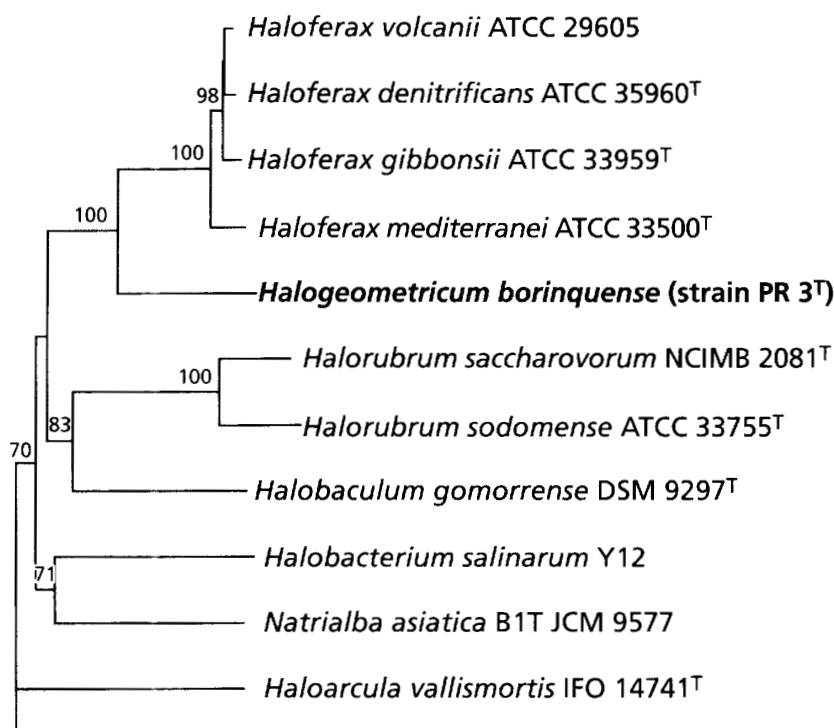

0.1

Fig. 4. Neighbour-joining distance tree of $16 \mathrm{~S}$ rRNA sequences. Bar represents 10 substitutions per 100 nucleotides. Bootstrap values higher than $70 \%$ are shown. Methanospirillum hungatei DSM $864^{\top}$ was used as the outgroup.
(Torreblanca et al., 1986), but it ran somewhat faster, indicating that they are not identical. The chromatogram and Azure A staining revealed that strain PR3 ${ }^{\mathrm{T}}$ lacks PGS. Other genera that lack PGS are Natrialba (Kamekura \& Dyall-Smith, 1995), Haloferax (Torreblanca et al., 1986), Halobaculum (Oren et al., 1995), Natronobacterium, Natronococcus (Tindall et al., 1984) and Natronomonas (Kamekura et al., 1997). Strain PR $^{\mathrm{T}}$ does not possess any of the common marker lipids associated with the more closely related halophilic genera such as Haloferax (Torreblanca et al., 1986), Halobaculum (Oren et al., 1995) or Natrialba (Kamekura \& Dyall-Smith, 1995). Based upon its TLC migration behaviour and staining characteristics, the glycolipid present in isolate PR $3^{T}$ would appear to be a novel glycolipid which may be useful as a marker for the new genus represented by this strain (Table 1).

Analysis of the 16S rRNA phylogenetic tree (Fig. 4) revealed that strain $P R 3^{\mathrm{T}}$ belongs to a separate phylogenetic branch, distantly related to Haloferax. The highest similarity existed between strain $\mathrm{PR} 3^{\mathrm{T}}$ and Haloferax volcanii ATCC 29605 (93.7\%). Similarity values between PR $3^{\mathrm{T}}$ and Haloarcula species are very low $(86 \cdot 2-87 \cdot 4 \%)$, showing that this organism is not phylogenetically close to this genus. Some physio- 
R. Montalvo-Rodríguez and others

Table 1. Main differences between strain $\mathrm{PR}^{\top}$ (Halogeometricum) and known genera of neutrophilic haloarchaea

Data were obtained from Kamekura \& Dyall-Smith (1995), Tindall (1992) and Torreblanca et al. (1986).

\begin{tabular}{|c|c|c|c|c|c|c|c|c|}
\hline Characteristic & Haloarcula & Halobacterium & Halobaculum & Halococcus & Haloferax & Halogeometricum & Halorubrum & Natrialba \\
\hline Cell shape & $\begin{array}{l}\text { Irregular rods, } \\
\text { triangles, rectangles }\end{array}$ & Rods & Rods & Cocci & $\begin{array}{l}\text { Irregular } \\
\text { rods, discs }\end{array}$ & $\begin{array}{l}\text { Short and long rods, } \\
\text { squares, triangles, } \\
\text { ovals }\end{array}$ & Rods & Rods \\
\hline Motility & D & + & \pm & - & D & + & t & + \\
\hline Glycolipid present & TDG-2 & $\begin{array}{c}\text { S-TDG-1, } \\
\text { S-TeGD }\end{array}$ & S-DGD-1 & S-DGD-1 & S-DGD-1 & NG† & S-DGD-3 & $\mathrm{S}_{2}-$ DGD-I \\
\hline PGS present & + & + & - & - & - & - & + & - \\
\hline $\begin{array}{l}\mathrm{G}+\mathrm{C} \text { content } \\
(\mathrm{mol} \%)\end{array}$ & $62 \cdot 7-68$ & $6670 \cdot 9$ & 70 & $57-66.6$ & $59 \cdot 5-64$ & $59 \cdot 1$ & $65 \cdot 3-71 \cdot 2$ & $60 \cdot 3 \cdot 63 \cdot 1$ \\
\hline
\end{tabular}

* $\mathrm{D}$, different reactions in different species.

$\dagger$ NG, novel glycolipid not identified.

logical properties of $\mathrm{PR}^{\mathrm{T}}$ also indicated that this organism did not belong to the genus Haloarcula. Characteristics such as the presence of gas vesicles, growth at $8 \%(\mathrm{w} / \mathrm{v}) \mathrm{NaCl}$, and the mucoid aspect of the colony do not fit into the description of the genus Haloarcula. These features are more typical of Haloferax species (Grant \& Larsen, 1990; Torreblanca et al., 1986).

Devereux et al. (1990) and Fry et al. (1991) have proposed that a similarity of less than $98 \%$ in a $16 \mathrm{~S}$ rRNA sequence should be considered evidence for separate species, and that with a similarity of less than 93-95\% strains should be classified in different genera. A similarity matrix constructed from a comparison of the $16 \mathrm{~S}$ rRNA sequences showed that the closest relative to strain PR3 was the genus Haloferax at only $92 \cdot 7-93 \cdot 3 \%$. The similarity of this strain to the other halophilic genera ranged between 86 and $89 \%$. The similarity of the PR3 16S rRNA to that from both Halorubrum and Halobacterium was only $88 \%$. Therefore, our proposal that isolate PR $3^{\mathrm{T}}$ represents a new genus that is remotely related to Haloferax appears justified on this basis.

Recently, minimal standards for the description of the Halobacteriales have been established (Oren et al., 1997). One of the analyses proposed is the characterization of polar lipid patterns, since this property has been shown to be particularly important in classification at the generic level. Based on polar lipid analysis, PR $3^{\mathrm{T}}$ could not be considered a species of Haloferax, which has S-DGD-1 as its major glycolipid. Similarity values of $16 \mathrm{~S}$ rRNA between PR $3^{\mathrm{T}}$ and members of the Haloferax are too low to consider $P R 3^{\mathrm{T}}$ a member of this genus. In addition, the GC content $(59.1 \mathrm{~mol} \%)$ is not in the range reported for Haloferax species (59.5-64 mol \%; Table 1).

These data strongly suggest that $\mathrm{PR} 3^{\mathrm{T}}$ represents a new genus and species. We propose that this strain be named Halogeometricum borinquense. Strain PR $3^{\mathrm{T}}$ has been designated the type strain of this group and has been deposited in the American Type Culture Collection as strain ATCC $700274^{\mathrm{T}}$.

\section{Description of Halogeometricum gen. nov.}

Halogeometricum Montalvo-Rodríguez, Vreeland, Oren, Kessel, Betancourt and López-Garriga (Ha.lo.ge.o.me'tri.cum. Gr. n. hals, halos the sea, salt. L. adj. geometricum geometrical; M.L. neut. n. Halogeometricum salty geometric shape).

Gram-negative pleomorphic cells (short and long rods, squares, triangles, and ovals). Colonies are pigmented (pink), small, circular, opaque, convex with an entire margin. Oxidase and catalase-positive. Chemoorganotrophic and aerobic. Grows anaerobically in the presence of nitrate. Arginine not fermented. Halophilic, requiring at least $8 \%(\mathrm{w} / \mathrm{v}) \mathrm{NaCl}$ for growth. The polar lipids are glycerol diether analogues of phosphatidylglycerol, phosphatidylglycerophosphate, and a single, as-yet-unidentified glycolipid. Phosphatidylglycerosulfate is absent. Certain carbohydrates can stimulate growth with acid production. The $\mathrm{G}+\mathrm{C}$ content of the type species is $59 \cdot 1 \mathrm{~mol} \%$. The type species is Halogeometricum borinquense.

\section{Description of Halogeometricum borinquense sp. nov.}

Halogeometricum borinquense (bo.rin.quen'se. M.L. fem. adj. borinquense of Borinquen, the native Indian name for Puerto Rico).

Cells are extremely pleomorphic (rods are $1-3 \times 1-2 \mu \mathrm{m}$ ), showing different shapes (short and long rods, squares, triangles and ovals). Motile by peritrichous flagella. Gas vesicles are present creating a milky appearance. The colonies are pink, small $(0 \cdot 5-1 \mathrm{~mm})$ and very mucoid. Chemo-organotrophic and aerobic. Anaerobic growth occurs with nitrate. Arginine not fermented. Requires at least $8 \%(\mathrm{w} / \mathrm{v})$ $\mathrm{NaCl}$ for growth. The optimal $\mathrm{NaCl}$ concentration range is $20-25 \%(\mathrm{w} / \mathrm{v})$ at $40{ }^{\circ} \mathrm{C}$; the optimal $\mathrm{Mg}^{2+}$ concentration range is $40-80 \mathrm{mM}$. The optimal temperature is $40{ }^{\circ} \mathrm{C}$ (in medium containing $20-25 \%(\mathrm{w} / \mathrm{v}$ ) $\mathrm{NaCl}$ and $\left.40-80 \mathrm{mM} \mathrm{Mg}^{2+}\right)$. Nitrate is reduced to nitrite with the production of gas. Indole is produced from tryptophan. Gelatin is strongly hydrolysed. 
Starch is not hydrolysed. Resistant to penicillin, kanamycin, ampicillin, vancomycin, tetracycline, erythromycin and chloramphenicol. Susceptible to novobiocin, bacitracin and sulfamethazone plus trimethoprim. Glucose, mannose, fructose, xylose, maltose, trehalose, cellobiose, raffinose and glycerol are used as carbon sources. Acid is produced from fructose, arabinose, ribose, xylose, lactose and sucrose. Isolated from the solar salterns of Cabo Rojo, Puerto Rico. The $\mathrm{G}+\mathrm{C}$ content of the type strain is $59 \cdot 1 \mathrm{~mol} \%$ (as determined by HPLC). The type strain is ATCC $700274^{\mathrm{T}}$.

\section{ACKNOWLEDGEMENTS}

We thank Dr Peter Cooke of the US Agricultural Research Service for assistance with the phase-contrast microscopy and Carlos Santos, Donato Seguí, Alejandro Cuello, Ricardo Maggie and Alejandro Ruiz-Acevedo for their help and comments. The work of R.M.R., C. B. and J.L.G was supported by the Minority Research Career of Excellence (MRCE-NSF) program (HRD-9543554), UPR-NASAEPSCOR (NCC5-215) and the Department of Biology, University of Puerto Rico, Mayaguez Campus. R.H.V. received support from grant number EAR 9714203 from the National Science Foundation

\section{REFERENCES}

Barns, S. M., Fundyga, R. E., Jeffries, M. W. \& Pace, N. R. (1994). Remarkable archaeal diversity in a Yellowstone National park hot spring environment. Proc Natl Acad Sci USA 91, 1609-1613

Bonelo, G., Ventosa, A., Megías, M. \& Ruiz-Berraquero, F. (1984). The sensitivity of halobacteria to antibiotics. FEMS Microbiol Lett 21, 341-345.

Colwell, R. R., Litchfield, C. D., Vreeland, R. H., Kiefer, L. A. \& Gibbons, N. E. (1979). Taxonomic studies of red halophilic bacteria. Int J Syst Bacteriol 29, 379-399.

Devereux, R., He, S.-H., Doyle, C. L., Orkland, S., Stahl, D. A., LeGall, J. \& Whitman, W. B. (1990). Diversity and origin of Desulfovibrio species: phylogenetic definition of a family. $J$ Bacteriol 172, 3609-3619.

Dussault, H. P. (1955). An improved technique for staining red halophilic bacteria. J Bacteriol 70, 484-485.

Felsenstein, J. (1993). PHYLIP (Phylogeny Inference Package), version 3.5.1. Seattle: Department of Genetics, University of Washington.

Fry, N. K., Warwick, S., Saunders, N. A. \& Embley, T. M. (1991). The use of $16 \mathrm{~S}$ ribosomal RNA analyses to investigate the phylogeny of the family Legionellaceae. J Gen Microbiol 137 , 1215-1222.

González, C., Gutiérrez, C. \& Ramírez, C. (1978). Halobacterium vallismortis sp. nov., an amylolytic and carbohydratemetabolizing extremely halophilic bacterium. Can J Microbiol 24, 710-715.

Grant, W. D. \& Larsen, H. (1990). Extremely halophilic archaeobacteria, order Halobacteriales ord. nov. In Bergey's Manual of Systematic Bacteriology, vol. 3, pp. 2216-2233. Edited by J. T. Staley, M. P. Bryant, N. Pfennig \& J. G. Holt. Baltimore: Williams \& Wilkins.

Hartmann, R., Sickinger, H.-D. \& Oesterhelt, D. (1980). Anaerobic growth of halobacteria. Proc Natl Acad Sci USA 77, 3821-3825.
Hochstein, L. I. \& Tomlinson, G. (1985). Denitrification by extremely halophilic bacteria. FEMS Microbiol Lett $\mathbf{2 7}$, 329-331.

Holding, A. J. \& Collee, J. G. (1971). Routine biochemical tests. Methods Microbiol 6A, 1-32.

Ihara, K., Watanabe, S. \& Tamura, T. (1997). Haloarcula argentinensis sp. nov. and Haloarcula mukohataei sp. nov., two new extremely halophilic archaea collected in Argentina. Int $J$ Syst Bacteriol 47, 73-77.

Kamekura, M. \& Dyall-Smith, M. (1995). Taxonomy of the family Halobacteriaceae and the description of two genera Halorubrobacterium and Natrialba. J Gen Appl Microbiol 41, 333-350.

Kamekura, M., Dyall-Smith, M. L., Upasani, V., Ventosa, A. \& Kates, M. (1997). Diversity of alkaliphilic halobacteria: proposals to transfer Natronobacterium vacuolatum, Natronobacterium magadii, and Natronobacterium pharaonis to Halorubrum, Natrialba, and Natronomonas gen. nov., respectively, as Halorubrum vacuolatum comb. nov., Natrialba magadii comb. nov., and Natronomonas pharaonis comb. nov. Int $J$ Syst Bacteriol 47, 853-857.

Kates, M. (1972). Techniques of Lipidology. New York: NorthHolland/American Elsevier.

McGenity, T. J. \& Grant, W. D. (1995). Transfer of Halobacterium saccharovorum, Halobacterium sodomense, Halobacterium trapanicum NRC 34021 and Halobacterium lacusprofundi to the genus Halorubrum gen. nov., as Halorubrum saccharovorum comb. nov., Halorubrum sodomense comb. nov., Halorubrum trapanicum comb. nov., and Halorubrum lacusprofundi comb. nov. Syst Appl Microbiol 18, 237-243.

Maidak, B. L., Olsen, G. J., Larsen, N., Overbeek, R., McCaughey, M. J. \& Woese, C. R. (1996). The Ribosomal Database Project (RDP). Nucleic Acids Res 24, 82-85.

Mancinelli, R. L. \& Hochstein, L. I. (1986). The occurrence of denitrification in extremely halophilic bacteria. FEMS Microbiol Lett 35, 55--58.

Matsubara, T., Lida-Tanaka, N., Kamekura, M., Moldovenau, N., Ishizuka, I., Onishi, H., Hayashi, A. \& Kates, M. (1994). Polar lipids of a non-alkalophilic extremely halophilic archaeobacterium strain 171: a novel bis-sulfated glycolipid. Biochim Biophys Acta 1214, 97-108.

Murray, R. G. E., Doetsch, R. N. \& Robinow, C. F. (1994). Determinative and cytological light microscopy. In Methods for General and Molecular Bacteriology, pp. 21-41. Edited by P. Gerhardt, R. G. E. Murray, W. A. Wood \& N. R. Kreig. Washington, DC: American Society for Microbiology.

Norton, C. (1992). Rediscovering the ecology of halobacteria. ASM News 58, 363-367.

Oren, A. (1983). Halobacterium sodomense sp. nov., a Dead Sea halobacterium with an extremely high magnesium requirement. Int J Syst Bacteriol 33, 381-386.

Oren, A., Gurevich, P., Gemmell, R. T. \& Teske, A. (1995). Halobaculum gomorrense gen. nov., sp. nov., a novel extremely halophilic archaeon from the Dead Sea. Int J Syst Bacteriol 45, $747-754$

Oren, A., Ventosa, A. \& Grant, W. D. (1997). Proposed minimal standards for description of new taxa in the order Halobacteriales. Int J Syst Bacteriol 47, 233-238.

Page, R. D. M. (1996). TREEVIEW: an application to display phylogenetic trees on personal computers. Comput Appl Biosci 12, 357-358.

Rainey, F. A., Ward-Rainey, N., Kroppenstedt, R. M. \& Stackebrandt, E. (1996). The genus Nocardiopsis represents a phylo- 
genetically coherent taxon and a distinct actinomycete lineage; proposal of Nocardiopsaceae fam. nov. Int $J$ Syst Bacteriol 46, 1088-1092.

Rodríguez-Valera, F., Ruiz-Berraquero, F. \& Ramos-Cormenzana, A. (1980). Isolation of extremely halophilic bacteria able to grow in defined inorganic media with single carbon sources. $J$ Gen Microbiol 119, 535-538.

Rodríguez-Valera, F., Juez, G. \& Kushner, D. J. (1983). Halobacterium mediterranei sp. nov., a new carbohydrate-utilising extreme halophile. Syst Appl Microbiol 4, 369-381.

Ross, H. N. M., Collins, M. D., Tindall, B. J. \& Grant, W. D. (1981). A rapid procedure for the detection of archaebacterial lipids in halophilic bacteria. J Gen Microbiol 123, 75-80.

Seghal, S. N. \& Gibbons, N. E. (1960). Effect of metal ions on the growth of Halobacterium cutirubrum. Can $J$ Microbiol 6 , 165-169.

Takashina, T., Hamamoto, T., Otozai, K., Grant, W. D. \& Horikoshi, K. (1990). Haloarcula japonica sp. nov. a new triangular halophilic archaebacterium. Syst Appl Microbiol 13, 177-181.

Thongthai, C., McGenity, T. J., Suntinanalert, P. \& Grant, W. D. (1992). Isolation and characterization of an extremely halophilic archaeobacterium from traditionally fermented Thai fish sauce (nam pla). Lett Appl Microbiol 14, 111-114.

Tindall, B. J. (1992). The family Halobacteriaceae. In The Prokaryotes: a Handbook on the Biology of Bacteria. Ecophysiology, Isolation, Identification and Applications, 2nd edn, pp. 768-810. Edited by A. Balows, H. G. Trüper, M. Dworkin, W. Harder \& K.-H. Schleifer. New York: Springer.

Tindall, B. J., Ross, H. N. M. \& Grant, W. D. (1984). Natronobacterium gen. nov. and Natronococcus gen. nov., two new genera of haloalkaliphilic archaebacteria. Syst Appl Microbiol 5, 41-57.

Tomlinson, G. A. \& Hochstein, L. I. (1976). Halobacterium saccharovorum sp. nov., a carbohydrate-metabolizing, extremely halophilic bacteria. Can J Microbiol 22, 587-591.

Torreblanca, M., Rodríguez-Valera, F., Juez, G., Ventosa, A., Kamekura, M. \& Kates, M. (1986). Classification of nonalkaliphilic halobacteria based on numerical taxonomy and polar lipid composition, and description of Haloarcula gen. nov. and Haloferax gen. nov. Syst Appl Microbiol 8, 89-99.

Vreeland, R. H. (1993). Taxonomy of halophilic bacteria. In The Biology of Halophilic Bacteria, pp. 105-134. Edited by R. H. Vreeland \& L. I. Hochstein. Boca Raton, FL: CRC Press. 